\author{
Agnieszka Lorek \\ Uniwersytet Ekonomiczny w Katowicach \\ e-mail: agnieszka.lorek@ue.katowice.pl
}

\title{
ZNACZENIE POSTAW I ZACHOWAŃ KONSUMENTÓW W KSZTALTOWANIU GOSPODARKI OBIEGU ZAMKNIĘTEGO
}

THE IMPORTANCE OF CONSUMER

ATTITUDES AND BEHAVIOURS IN SHAPING THE CIRCULAR ECONOMY

DOI: $10.15611 /$ pn.2018.533.14

JEL Classification: Q5

Streszczenie: Cele artykułu to prezentacja i ocena znaczenia zachowań konsumenckich dla możliwości wdrożenia gospodarki obiegu zamkniętego dążącej do zmniejszenia negatywnego oddziaływania procesów produkcyjnych i konsumpcyjnych na środowisko naturalne poprzez tworzenie zamkniętych pętli obiegu surowców. W artykule zastosowano analizę dostępnej literatury przedmiotu, raportów tematycznych oraz danych statystycznych. Wykorzystano również badania gospodarstw domowych województwa śląskiego. Uznano, że dla praktycznej implementacji gospodarki obiegu zamkniętego zasadnicze znaczenie mają trzy płaszczyzny aktywności konsumenckiej: grupa I obejmująca postawy i zachowania związane z decyzją o zakupie; grupa II, odnosząca się do postaw i zachowań dotyczących już zakupionych produktów, np. decyzji związanych z ich naprawą i dalszym użytkowaniem oraz tendencji w tym zakresie; grupa III dotycząca sposobów postępowania z odpadami pokonsumpcyjnymi (analizowano tendencje dotyczące recyklingu na podstawie badań przeprowadzonych wśród gospodarstw domowych województwa śląskiego).

Słowa kluczowe: gospodarka obiegu zamkniętego, zachowania konsumentów, województwo śląskie.

Summary: The main goal of the article is to present and evaluate the importance of consumer behaviour for the possibilities of implementing the circular economy which aims to reduce the negative impact of production and consumption processes on the natural environment by creating closed loops of resources. The basic research methods are the analysis of the available subject literature, thematic reports and statistical data. The paper also presents results of surveys among households in the Silesian Voivodeship and recognizes that for the practical implementation of the circular economy, three groups of consumer activity are of fundamental importance: group I includes attitudes and behaviours related to the purchase decision; group II refers to attitudes and behaviours regarding already purchased products, eg. decisions related to their repair and further use, and trends in this area; group III deals with the treatment of post-consumer waste (analysis of recycling trends based on surveys carried out among households in the Śląskie Voivodeship).

Keywords: circular economy, consumer behaviour, Silesian Voivodeship. 


\section{Wstęp}

Druga połowa XX wieku i początek wieku XXI to okres, kiedy społeczeństwo zaczęło zauważać i brać pod uwagę rosnące zagrożenie ze strony zanieczyszczenia środowiska naturalnego i wyczerpywania zasobów. Jednym z szeroko dyskutowanych rozwiązań problemu kurczenia się zasobów i presji związanej z powstawaniem odpadów jest koncepcja gospodarki obiegu zamkniętego ${ }^{1}$, która dąży do zmniejszenia skutków negatywnego oddziaływania procesów produkcyjnych i konsumpcyjnych na środowisko naturalne. Gospodarka cyrkularna we współczesnym ujęciu stanowi system naczyń połączonych. W koncepcji tej bierze się pod uwagę zarówno procesy przyrodnicze i równowagę $\mathrm{w}$ ich funkcjonowaniu, jak i relacje zachodzące ze społeczeństwem i z gospodarką. Jednym z elementów wspierających wdrażanie koncepcji gospodarki okrężnej jest świadomość ekologiczna konsumentów. To właśnie klienci, dokonując wyboru, mogą się kierować bezpośrednio lub pośrednio kryteriami ekologicznymi lub społecznymi, a tym samym wspierać proekologiczne rodzaje produkcji i rozwój przemysłu recyklingowego.

Głównym celem artykułu jest prezentacja i ocena znaczenia zachowań konsumenckich jako podstawy wdrożenia zasad gospodarki obiegu zamkniętego. Uznano, że dla praktycznej implementacji gospodarki obiegu zamkniętego zasadnicze znaczenie mają trzy płaszczyzny aktywności konsumenckiej:

- grupa I - postawy i zachowania związane z decyzją o zakupie i samym zakupem;

- grupa II - postawy i zachowania dotyczące już zakupionych produktów, np. decyzje związane $\mathrm{z}$ ich naprawą i dalszym użytkowaniem;

- grupa III - sposoby postępowania z odpadami.

Podstawową metodą badawczą zastosowaną w artykule jest analiza dostępnej literatury przedmiotu, raportów tematycznych oraz danych statystycznych. W artykule wykorzystano również badania wśród gospodarstw domowych województwa śląskiego:

- w latach 1999-2000 (badania finansowane przez Komitet Badań Naukowych, grant nr 1H02C03615, 1999 - 922 gospodarstwa domowe, 2000 - 1086 gospodarstw domowych),

- 2012-2014 (badania wykonane w ramach badań statutowych prowadzonych przez Katedrę Zarządzania Ochroną Środowiska Uniwersytetu Ekonomicznego w Katowicach, 466 gospodarstw domowych),

- w roku 2018 - badania własne przeprowadzone wśród 355 gospodarstw domowych województwa śląskiego.

\footnotetext{
${ }^{1}$ W artykule terminy ,gospodarka okrężna”, ,gospodarka obiegu zamkniętego”, ,,gospodarka cyrkularna" są traktowane jako synonimy.
} 


\section{Idea gospodarki obiegu zamkniętego}

Gospodarka obiegu zamkniętego była przedmiotem zainteresowania wielu badaczy, a istotne założenia i podstawy teoretyczne dotyczące koncepcji gospodarki okrężnej zostały przedstawione w pracach W.R. Stahela [1976]. W latach 70 i 80. W. Stahel i G. Reday zaprezentowali wizję gospodarki o zamkniętym obiegu i jej wpływ na tworzenie miejsc pracy, konkurencyjność gospodarczą, oszczędność zasobów oraz zapobieganie powstawania odpadów. Całościowy model gospodarki okrężnej (circular economy) został wprowadzony w literaturze światowej przez D. Pearce'a i R. Turnera [1990], którzy inspirowali się poglądami K. Bouldinga [1966]. W dyskursie na temat gospodarki obiegu zamkniętego generalnie można wyróżnić dwa nurty, które przekładają się na jej różne definiowanie i/lub interpretację:

1. Nurt pierwszy - zorientowany na minimalizację zużycia zasobów i potrzebę tworzenia zamkniętych pętli ich obiegu, a przez to zmniejszenie presji na środowisko (por. [Sauvé, Bernard, Sloan 2016; Preston 2012; Mitchell 2015]). Podobnie koncepcja gospodarki o zamkniętym obiegu jest przedstawiona w wielu dokumentach i opracowaniach instytucji międzynarodowych. Komisja Europejska w dokumencie pn. Zamknięcie obiegu - plan działania UE dotyczący gospodarki o obiegu zamkniętym [COM (2015) 614 final] stwierdza, że w gospodarce o obiegu zamkniętym , (...) w miarę możliwości wartość produktów, materiałów i zasobów utrzymywana jest w gospodarce tak długo jak to możliwe, a generowanie odpadów zminimalizowane". Europejska Agencja Środowiska [EEA 2014] twierdzi, że gospodarka obiegowa „,(..) odnosi się głównie do fizycznych i materialnych aspektów zasobów gospodarki - koncentruje się na recyklingu, ograniczaniu i ponownym wykorzystaniu fizycznych nakładów na gospodarkę i wykorzystaniu odpadów jako zasobów, prowadząc do zmniejszenia zużycia zasobów pierwotnych". Podejście skoncentrowane na minimalizacji zużycia zasobów jest również obecne w analizach Klubu Rzymskiego [2015; 2016], które podkreślają potrzebę przejścia na: „(...) gospodarkę obiegu zamkniętego, w której produkty są zaprojektowane w celu łatwego recyklingu, ponownego użycia, demontażu i regeneracji”.

2. Nurt drugi - to podejścia zawierające dodatkowe wymiary i wychodzące poza problematykę gospodarowania zasobami naturalnymi. Najszerszy sposób definiowania gospodarki obiegowej odnosi się do koncepcji zrównoważonego rozwoju, ale jest to stosunkowo rzadkie podejście. Według badań J. Kirchherra, D. Reike i M. Hekkerta [2017], którzy przeanalizowali 114 definicji gospodarki o obiegu zamkniętym, tylko $13 \%$ z nich odnosiło się do wszystkich trzech wymiarów zrównoważonego rozwoju. Na gruncie gospodarki europejskiej szersze ujęcie gospodarki obiegu okrężnego przykładowo odnajdziemy w analizach:

- Francuskiej Agencji Zarządzania Środowiskiem i Energią ADEME [2014], według której celem gospodarki o obiegu zamkniętym jest ograniczenie wpływu konsumpcji zasobów na środowisko i poprawa dobrostanu społecznego; 
- w raportach przygotowanych przez Fundację Ellen MacArthur [2012; 2013; 2015], w których przykłada się uwagę do odbudowy kapitału zarówno naturalnego, jak i społecznego.

Dodatkowe wymiary gospodarki okrężnej są również silnie akcentowane w literaturze dotyczącej chińskiego modelu gospodarki cyrkularnej, co jest związane ze zmianami politycznymi zachodzącymi w Chinach. Autorzy analizujący chiński model (por. [Su i in. 2013; Geng, Doberstein 2008]) zwracają uwagę, że sektor gospodarki o obiegu zamkniętym stopniowo wykracza poza kwestie związane z zarządzaniem materiałami i obejmuje inne aspekty, takie jak efektywność energetyczna, gospodarka gruntami, ochrona gleby i wody. Obszerna analiza rozumienia pojęcia gospodarki o obiegu zamkniętym w odniesieniu do gospodarki chińskiej i europejskiej została zawarta w artykule [McDowall i in. 2017]. W tym opracowaniu autorzy stwierdzają: „,...) koncepcja gospodarki o obiegu zamkniętym leży u podstaw chińskiej retoryki politycznej środowiska”, a władze chińskie podkreślają „,...) potrzebę zbudowania społeczeństwa oszczędzającego zasoby i przyjaznego środowisku oraz ekologicznej cywilizacji” [McDowall i in. 2017].

\section{Konsument w gospodarce obiegu zamkniętego}

\subsection{Postawy i zachowania związane z decyzją o zakupie i z samym zakupem}

Przemiany świadomościowe dokonujące się pod wpływem czynników ekonomicznych, społecznych, kulturowych oraz wymiany informacji tworzą potrzeby konsumpcyjne uzewnętrzniające się w postaci zachowań konsumenckich. To uświadomiony o oddziaływaniu środowiskowym konsument może wpływać na kształt rynku produktów przyjaznych środowisku. Wybory dokonywane przez miliony konsumentów mogą wspierać rozwój gospodarki o obiegu zamkniętym lub go utrudniać. Decyzje konsumentów zależą w dużej mierze od uzyskania wiarygodnej informacji o produktach, ich asortymencie, cenach produktów oraz istniejących uregulowaniach prawnych. Istotną barierą wdrażania gospodarki okrężnej są również utrwalone zachowania i nawyki ludzi. Według raportu Ellen MacArthur Foundation and McKinsey Center for Business and Environment [2015] menedżerowie biznesowi i konsumenci, dorastając w liniowych systemach produkcji i we wzorcach konsumpcji, rzadko szukają możliwości związanych z rozwojem gospodarki okrężnej. Jest to jedna z najpoważniejszych, a jednocześnie najbardziej niedoceniana, bariera skutecznego wdrażania rozwiązań gospodarki okrężnej. Badania konsumenckie pokazują w tym zakresie rozległą lukę między intencjami i działaniami. Według sondażu z 2014 r. [Komisja Europejska 2014] prawie wszyscy Europejczycy (96\%) uważają, że Europa powinna wydajniej wykorzystywać zasoby, ale tylko $21 \%$ z nich wydzierżawiło lub wynajęło produkt, zamiast go kupować, a tylko $27 \%$ skorzystało z programów dzielenia się (sharing schemes). Istotnym elementem warunkującym możliwość przejścia na gospodarkę obiegu zamkniętego jest upowszechnienie jednolitych 
i wiarygodnych metod pomiaru i etykietowania efektywności środowiskowej. Rozwiązania takie zwiększają wśród konsumentów poziom akceptacji dla ekologicznego oznakowania produktów. To właśnie ekoetykietowanie zaliczane jest do narzędzi tzw. produktozorientowanych i powoduje zwiększenie świadomości ekologicznej wśród konsumentów. Badania konsumentów odnośnie do preferencji zakupu produktów ekologicznych przeprowadzone w UE w 2012 roku wykazały, że konsumenci w UE chętnie by kupowali ekologiczne produkty i płacili za nie wyższą cenę (77\%) pod warunkiem wiarygodnej informacji środowiskowej [Komisja Europejska 2013].

\subsection{Postawy i zachowania dotyczące już zakupionych produktów}

W tym aspekcie ważną barierą wdrażania gospodarki obiegu zamkniętego są istniejące praktyki przedsiębiorstw dążące do skrócenia cyklu życia produktów. Planowane ograniczanie żywotności produktów jest kwestią problematyczną pod wieloma względami - zmniejszając trwałość towarów konsumpcyjnych, zwiększa się zużycie zasobów oraz liczbę odpadów do przetworzenia. Praktyki takie zniechęcają konsumentów do podejmowania napraw zepsutego sprzętu. Przykładowo według sondażu „Postawy Europejczyków wobec tworzenia jednolitego rynku produktów ekologicznych" [Komisja Europejska 2013] prawie połowa (47\%) respondentów w poprzednim roku zdecydowała się nie oddawać wadliwego produktu do naprawy, ponieważ jej koszty okazały się zbyt wysokie. Jak wskazują dane przytaczane przez Europejski Komitet Ekonomiczno-Społeczny, średni okres eksploatacji sprzętu AGD wynosi obecnie 6-8 lat, podczas gdy 20 lat temu wynosił 10-12 lat [European Economic and Social Committee...]. Tendencję tę potwierdzają badania przeprowadzone wśród polskich konsumentów w województwie śląskim. Znacząco zmniejszyła się tu liczba osób dokonujących naprawy uszkodzonego sprzętu elektronicznego i elektrycznego (37\% gospodarstw domowych w 1999 r., 15,6\% w okresie 2013-2014 i jedynie 13\% w 2018 roku). Podobne tendencje można zaobserwować odnośnie do innych grup produktów. W badaniach ankietowych prowadzonych w roku 2018 gospodarstwa domowe deklarowały, że:

- Odzież i obuwie są naprawiane i użytkowane w dalszym ciągu jedynie w ok. 5\% gospodarstw domowych, a 7\% odsprzedaje je, o ile jest to możliwe. Rzeczy te najczęściej są oddawane innym (37,8\%).

- Niepotrzebne książki - 6,4\% ankietowanych oddaje je innym, 4,9\% je sprzedaje. Najczęstszym sposobem postępowania konsumentów jest wyrzucenie książek do pojemników na papier (ok. 50\% ankietowanych), a ok. 19\% respondentów wyrzuca je do pojemników na odpady zmieszane.

- Niepotrzebne lub uszkodzone meble - około $24 \%$ gospodarstw domowych oddaje je innym do dalszego użytkowania. Meble są sprzedawane kolejnym użytkownikom w ok. 19\% gospodarstw domowych, a jedynie 6,7\% je ankietowanych naprawia. 


\subsection{Sposoby postępowania z odpadami}

W gospodarce obiegu zamkniętego szczególną rolę przypisuje się gospodarce odpadami i rozwojowi przemysłu recyklingowego, a materiały, które mogą zostać poddane recyklingowi, są z powrotem wprowadzane do gospodarki jako nowy surowiec, co pozwala zwiększyć bezpieczeństwo dostaw. Pomimo obserwowanych w wielu krajach pozytywnych tendencji dotyczących wytwarzania odpadów i ich recyklingu, istnieje na tym polu duży potencjał zmiany odnośnie do postaw konsumentów względem odpadów pokonsumpcyjnych i postępowania z takimi odpadami. Dobrze ilustrują to dane dotyczące selekcjonowania odpadów przez mieszkańców województwa śląskiego. 1 stycznia 2012 r. weszła w życie zmiana Ustawy z dnia 13 września 1996 r. o utrzymaniu czystości i porządku w gminach oraz niektórych innych ustaw. Od tego dnia gminy miały 18 miesięcy na wprowadzenie zmian i wdrożenie na swoim terenie nowych systemów gospodarki odpadami komunalnymi. Według tych uregulowań osoby segregujące odpady ponoszą mniejsze opłaty, przy czym wymóg zróżnicowania opłaty jest obligatoryjny. Według badań ankietowych przeprowadzonych wśród gospodarstw domowych województwa śląskiego wyraźnie widać wpływ zmieniającego się prawa na deklaracje i zachowania konsumentów odnośnie do selekcjonowania odpadów. W latach 1999-2000 selekcjonowanie odpadów deklarowało około 35-36\% gospodarstw domowych. Na początku wprowadzania zmian systemowych odpady selekcjonowano w około $57 \%$ gospodarstw. Po wdrożeniu systemu (dane ankietowe dla lat 2013-2014 i 2018) selekcja była dokonywana w około $80 \%$ gospodarstw domowych; poziom ten utrzymuje się. Wciąż niezagospodarowanym obszarem pozostaje $20 \%$ gospodarstw domowych, które nie chcą uczestniczyć w systemie segregacji, pomimo zachęt finansowych. Istotną grupą odpadów, które w stosunkowo łatwy sposób mogą być przetworzone na użyteczny surowiec, są odpady organiczne. Na podstawie wyników badan ankietowych przeprowadzonych na konsumentach województwa śląskiego można zaobserwować dwie tendencje korzystne dla wdrażania gospodarki obiegu zamkniętego, mianowicie:

1. Zmniejszenie liczby osób deklarujących wyrzucanie bioodpadów bezpośrednio do pojemników na odpady zmieszane (tendencja spadkowa od ok. 90\% w 1999 r., 50\% w okresie 2013-2014, do 37\% w 2018 r.),

2. Rosnąca liczba respondentów, którzy wybierają kompostowanie jako sposób zagospodarowania odpadów organicznych (tendencja wzrostowa od ok. 20\% w 1999 r. do ok. 46\% w okresie 2013-2014). W 2018 r. samodzielnie kompostowało odpady $32 \%$ ankietowanych, a $30 \%$ deklarowało korzystanie ze specjalnych pojemników na bioodpady dostarczanych przez gminy.

\section{Zakończenie}

Dla wdrażania koncepcji zrównoważonego rozwoju wielkie znaczenie ma kształtowanie społecznie i ekologicznie odpowiedzialnych wzorców konsumpcji i postępowania z odpadami pokonsumpcyjnymi. Zmiana tych wzorców jest wyzwaniem dla 
wszystkich społeczeństw, a ludzkie aspiracje konsumpcyjne muszą uwzględniać ograniczoną wielkość dostępnych zasobów biosfery. Wprawdzie panujące wzorce wciąż trudno uznać za zrównoważone, jednak można zauważyć znaczące zmiany. Na podstawie wyników przeprowadzonych badań można stwierdzić rosnący udział konsumentów segregujących odpady pokonsumpcyjne i kompostujących odpady organiczne, lecz mimo to istnieje grupa osób niechętnych takim rozwiązaniom, co wymaga dalszych działań edukacyjnych. Niepokojące tendencje dotyczą także postępowania z produktami uszkodzonymi lub niepotrzebnymi, które najczęściej nie są naprawiane, sprzedawane lub oddawane, zasilając strumień odpadów. W tym zakresie pomocne może być zastosowanie nowoczesnych technologii. Przykładowo Porter i Heppelmann [2014] opisują, w jaki sposób model oparty na usługach, wspierany przez Internet of Things i rozwój technologii cyfrowych, zwiększy zaangażowanie klientów. Wykorzystanie Internet of Things oznacza, że większość dostawców będzie w stanie monitorować i utrzymywać stały kontakt ze swoim sprzętem cyfrowym, a także dostawcy będą w stanie przewidzieć problemy, zanim się one pojawią, i naprawić je bez awarii sprzętu. Drugą rzeczą, którą może ułatwić wykorzystanie nowoczesnych technologii cyfrowych, jest umożliwienie utrzymania kontroli nad produktami i zaplanowanie ich zwrotu oraz kolejnego cyklu życia. Należy jednak zauważyć, iż przejście na gospodarkę o obiegu zamkniętym jest zmianą systemową. Aby gruntownie zmienić sposoby produkcji i konsumpcji oraz przekształcić odpady w produkty o wysokiej wartości dodanej, potrzeba nowych technologii, procesów, usług i modeli biznesowych, które ukształtują przyszłość gospodarki i społeczeństwa, niezbędna jest także aktywność ze strony władz publicznych dotycząca kreowania odpowiednich uregulowań prawnych czy też działań edukacyjnych.

\section{Literatura}

ADEME (French Environment and Energy Management Agency), 2014, Economie Circulaire: Notions, version modifiée octobre 2014.

Boulding K.,1966, The Economics of the Coming Spaceship Earth, [w:] H. Jarrett (red.), Environmental Quality in a Growing Economy, Johns Hopkins University, Baltimore, MD.

Communication from the Commission to the European Parliament, the Council, the European Economic and Social Committee and the Committee of the Regions, Closing the loop - An EU action plan for the Circular Economy, COM/2015/0614 final.

EEA (European Environment Agency), 2014, Resource-efficient Green Economy and EU Policies, Publications Office of the European Union, Luxembourg.

Elen MacArthur Foundation, 2012, Towards the Circular Economy, vol. 1, An Economic and Business Rationale for an Accelerated Transition, https://www.ellenmacarthurfoundation.org/publications (29.03.2018).

Ellen MacArthur Foundation, 2013, Towards the Circular Economy, vol. 2, Opportunities for the Consumer Goods Sector, https://www.ellenmacarthurfoundation.org/publications (29.03.2018).

Ellen MacArthur Foundation, 2015, Towards a Circular Economy: Business Rationale for an Accelerated Transition, https://www.ellenmacarthurfoundation.org/publications (29.03.2018). 
Ellen MacArthur Foundation and McKinsey Center for Business and Environment, 2015, Growth within: A Circular Economy Vision for a Competitive Europe, https://www.ellenmacarthurfoundation. org/publications (29.03.2018).

Eurostat, http://ec.europa.eu/eurostat (11.05.2018).

European Economic and Social Committee 2014/C 67/05, Opinion of the European Economic and Social Committee on 'Towards more sustainable consumption: industrial product lifetimes and restoring trust through consumer information' (own-initiative opinion), Official Journal of the European Union.

Geng, Y., Doberstein, B., 2008, Developing the circular economy in China: Challenges and opportunities for achieving 'leapfrog development", International Journal of Sustainable Development \& World Ecology, 15, s. 231-239.

Kirchherr J., Reike D., Hekkert M., 2017, Conceptualizing the circular economy: An analysis of 114 definitions, Resources, Conservation \& Recycling, 127 (2017), s. 221-232.

Klub Rzymski, 2015, The Circular Economy and Benefits for Society Jobs and Climate Clear Winners in an Economy Based on Renewable Energy and Resource Efficiency. A study pertaining to Finland, France, the Netherlands, Spain and Sweden, www.clubofrome.org (16.03.2018).

Klub Rzymski, 2016, The Circular Economy and Benefits for Society Jobs and Climate Clear Winners in an Economy Based on Renewable Energy and Resource Efficiency. A study pertaining to the Czech Republic and Poland, www.clubofrome.org (16.03.2018).

Komisja Europejska, 2013, Flash Eurobarometer 367: Attitudes of Europeans towards Building the Single Market for Green Products.

Komisja Europejska, 2014, Flash Eurobarometer 388: Attitudes of Europeans towards Waste Management and Resource Efficiency.

McDowall W., Geng Y., Huang B., Bartekov'a E., Bleischwitz R., Türkeli S., Kemp R., Doménech T., 2017, Circular economy policies in China and Europe, Journal of Industrial Ecology, https://www. researchgate.net/publication/316722262 (16.03.2018).

Mitchell P., 2015, Employment and the circular economy - Job Creation through resource efficiency in London, WRAP for the London Sustainable Development Commission, the London Waste and Recycling Board and the Greater London Authority.

Pearce D.W., Turner R.K., 1990, Economics of Natural Resources and the Environment, Johns Hopkins University Press, Baltimore, MD.

Porter M.E., Heppelmann J.E., 2014, How smart, connected products are transforming competition, Harvard Business Review, November 2014 Issue

Preston F., 2012, A Global Redesign? Shaping the Circular Economy, Briefing Paper, Chatham House, London.

Sauvé S., Bernard S., Sloan P., 2016, Environmental sciences, sustainable development and circular economy: Alternative concepts for trans-disciplinary research, Environmental Development, vol. 17 , s. 48-56.

Stahel W., Reday G., 1976, Report The Potential for Substituting Manpower for Energy, Vantage Press, New York.

Stahel W., Reday G., 1981, Jobs for Tomorrow, the Potential for Substituting Manpower for Energy, Vantage Press, New York.

Su B., Heshmati A., Geng Y., Yu X., 2013, A review of the circular economy in China: Moving from rhetoric to implementation, Journal of Cleaner Production, vol. 42, s. 215-227. 